\title{
PENGARUH KOMPETENSI DAN PELATIHAN GURU TERHADAP PROFESIONALISME GURU DENGAN MMOTIVASI SEBAGAI VARIABEL INTERVENING DI MI, MTS DAN SMK YAYASAN PESANTREN DARUL ABROR KEDUNGJATI
}

\author{
Yuliana1), Haryadi2), Ade Irma Anggraeni3) \\ Program Pascasarjana Magister Manajemen Universitas Jendral Soedirman Purwokerto ${ }^{1)}$ \\ Fakultas Ekonomi dan Bisnis Magister Manajemen Universitas Jendral Soedirman \\ Purwokerto 233 ) \\ Email corresponding author : yuli28yuliana@gmail.com
}

\begin{abstract}
This research was conducted in order to determine the effect competencies, and training in the professionalism of teachers with motivation as an intervening variable in MI, MTs, and SMK Yayasan Pondok Pesantren Darul Abror Kedungjati. This research was a quantitative research, using multiple linear regression analysis. The location of the study was conducted in MI, MTs, and SMK Yayasan Pondok Pesantren Darul Abror Kedungjati. The population in this study were all teachers in MI, MTs, and SMK Yayasan Pondok Pesantren Darul Abror Kedungjati. The total sample was same with the study of population that were 43 teachers in MI, MTs, and SMK Yayasan Pondok Pesantren Darul Abror Kedungjati.The results of this study were competency variables having a positive and significant impact on the motivation of teachers. With the compentence in accordance with the workload, it could increase the motivation of teachers getting better and improving. Competence variable, the variable training and motivational variables together have the positive and significant impact on the professionalism of teachers. Teachers who had high competence, training and motivation, then the teacher would have a high teacher professionalism. Variable competencies, and training together had a positive and significant impact on the professionalism of teachers with motivation as an intervening variable / mediation. Training variables had a positive effect but it was not significant to teachers' motivation.

Keywords: competencies, training, motivation, professionalism of teacher
\end{abstract}

\begin{abstract}
ABSTRAK
Penelitian ini dilakukan dengan tujuan untuk mengetahui, kompetensi, dan pelatihan terhadap profesionalisme guru dengan motivasi sebagai variabel intervening di MI, MTs, dan SMK Yayasan Pondok Pesantren Darul Abror Kedungjati. Penelitian ini merupakan penelitian kuantitatif, menggunakan analisis regresi linier berganda. Lokasi penelitian dilaksanakan di MI, MTs, dan SMK Yayasan Pondok Pesan tren Darul Abror Kedungjati. Populasi dalam penelitian ini semua guru di MI, MTs, dan SMK Yayasan Pondok Pesantren Darul Abror Kedungjati. Jumlah sampel penelitian sama dengan populasi penelitian sebanyak 43 guru di MI, MTs, dan SMK Yayasan Pondok Pesantren Darul Abror Kedungjati. Hasil penelitian ini adalah variabel kompetensi memiliki pengaruh positif dan signifikan terhadap motivasi guru. Dengan adanya kompetensi yang baik sesuai dengan beban kerja, maka dapat menambah motivasi guru semakin baik dan meningkat. Variabel kompetensi, variabel pelatihan, dan variabel motivasi secara bersama-sama memilki pengaruh positif dan signifikan terhadap profesionalisme guru. Guru yang memiliki kompetensi, pelatihan dan motivasi yang tinggi, maka guru tersebut akan memiliki profesionalisme guru yang tinggi. Variabel kompetensi dan pelatihan secara bersama-sama memiliki pengaruh positif dan signifikan terhadap profesionalisme guru dengan motivasi sebagai variabel intervening. Variabel pelatihan memiliki pengaruh positif tetapi tidak signifikan terhadap motivasi guru.

Kata kunci: kompetensi, pelatihan, motivasi, profesionalisme guru
\end{abstract}

\section{PENDAHULUAN}

Guru adalah tenaga pendidik yang memiliki kewajiban mengajarkan sutau ilmu pengetahuan di lembaga pendidikan formal, yang bertugas membuat rencana pembelajaran, melakukan proses pembelajaran, dan menilai hasil pembelajaran, serta meningkatkan pelatihan dan bimbingan sebagai tenaga profesional. Menurut Kunandar (2001) Profesionalisme adalah suatu sifat, kondisi, dan kualitas yang harus dimiliki seseorang dalam hal keahlian dan kewenangan seseorang yang berkaitan dengan profesi. Guru yang memiliki profesionalisme tinggi akan 
meningkat kualitas dan kuantitas profesionalnya melalui berbagai cara dan strategi dalam kemajuan dari segi pendidikannya (Surya, 2003). Profesionalisme guru menjadi factor yang penting dan sangat di butuhkan oleh seorang guru, agar guru dapat bekerja dengan baik dalam menjalankan tugas pokoknya dan meningkatkan kualitas sumber daya manusianya yang lebih baik. Hal tersebut menunjukkan bahwa pentingnya upaya peningkatan kualitas pendidikan guru yang harus dilakukan terus menerus secara berkelanjuatan. Berdasarkan data yang diperoleh, menunjukkan hasil sebagai berikut:

\begin{tabular}{cccc}
\multicolumn{4}{c}{ Tabel 1.1 Penilaian guru berdasarkan SKP (Sasaran Kinerja Pegawai) } \\
\hline Nilai SKP & Keterangan & Jumlah Guru & Persentase $\%$ \\
\hline $91-100$ & Sangat Baik & 0 & $0 \%$ \\
$76-90$ & Baik & 35 & $81,4 \%$ \\
$61-75$ & Cukup & 8 & $18,6 \%$ \\
$51-60$ & Sedang & 0 & $0 \%$ \\
$\leq 50$ & Buruk & 0 & $0 \%$ \\
\hline Jumlah & & 43 & $100 \%$
\end{tabular}

Sumber : Arsip penilaian guru MI, MTs, dan SMK Darul Abror Kedungjati 2017.

Dari penjelasan diatas menjadi alasan dan bahan pertimbangan kenapa profesionalisme guru sangat penting dan harus ditingkatkan. Berdasarkan data yang diperoleh, menunjukkan bahwa jumlah guru yang berada di Yayasan Pondok Pesantren Darul Abror Kedungjati yang berjumlah 43 guru. Hasil penilaian kompetensi guru yang memperoleh prosentase 91-100 kategori sangat baik 0 atau $0 \%$, guru yang memperoleh presentase $76-90$ ada 35 orang atau $81,4 \%$ kategori baik, guru yang memperoleh prosentase $61-75$ ada 8 orang atau 18,6\% kategori cukup. Sedangkan guru yang memperoleh prosentase 51-60 dan prosentase $\leq 50$ kategori buruk 0 atau 0\%. Dengan hasil rata-rata kategori baik 81,4\% dan hasil kategori cukup 18,6\% perlu ditingkatkan untuk mencapai kategori sangat baik, yaitu dengan prosentasenya 91-100 persen. Sedangkan penilaian yang dilakukan Kepala Madrasah guna meminimalkan kesulitan atau hambatan yang sering dialami oleh seorang guru.

Tabel 1.2 Klasifikasi Penilaian Supervisi Guru

\begin{tabular}{cccc}
\hline Nilai Supervisi & Keterangan & Jumlah Guru & Persentase \% \\
\hline $90-100$ & Sangat Baik & 0 & $0 \%$ \\
$80-89$ & Baik & 12 & $27,9 \%$ \\
$65-79$ & Cukup Baik & 31 & $72,1 \%$ \\
$55-64$ & Kurang Baik & 0 & $0 \%$ \\
$0-54$ & Sangat Kurang & 0 & $0 \%$ \\
\hline Jumlah & & 43 & $100 \%$ \\
\hline
\end{tabular}

Sumber: Arsip supervisi guru MI, MTs, dan SMK Darul Abror Kedungjati 2017.

Berdasarkan hasil penilaian supervisi guru yang dilakukan kepala sekolah di Yayasan Pondok Pesantren Daraul Abror Kedungjati, guru yang meperoleh prosentase 90-100 kategori sangat baik 0 atau $0 \%$, untuk guru yang memperoleh presentase $80-89$ ada 12 orang atau $27,9 \%$ kategori baik. Sedangkan guru yang memperoleh prosentase $65-79$ ada 31 orang atau $72,1 \%$ kategori cukup. Sedangkan guru yang memperoleh prosentase 55-64 kategori kurang baik dan prosentase 0-54 kategori sangat kurang 0 atau 0\%. Dengan hasil kategori baik 27,9\% dan hasil kategori cukup 72,1\% perlu ditingkatkan untuk mencapai kategori baik posentase 90-100 dan sangat baik prosentasenya 90-100 persen, guna meningkatkan kualitas kompetensi guru sehingga profesionalisme guru semakin meningkat dan lebih baik di Yayasan Pondok Pesantren Darul Abror Kedungjati.

Selain itu ada beberapa permasalahan, hambatan, persoalan, dan tantangan yang terjadi di lapangan yang dihadapi guru-guru dalam proses belajar mengajar di bawah naungan Yayasan 
Pondok Pesantren Darul Abror Kedungjati. Beberapa permasalah yang muncul seperti masih rendahnnya kualitas profesionalisme guru. Rendahnya profesionalisme dipicu dengan berbagai permasalahan seperti adanya kesulitan atau hambatan yang sering dialami oleh seorang guru. Dalam hal ini khususnya guru MI, MTs, dan SMK Yayaan Darul Abror Kedungjati, permasalahan yang terjadi berkaitan dengan kualitas guru yang masih belum memuaskan, perencanaan proses pembelajaran yang belum optimal, minimnya pengalaman dan pelatihan yang diterima guru, dan masih terdapat guru yang mengajar tidak sesuai dengan latar belakang pendidikan yang dimilikinya. Kondisi ini memerlukan adanya pengembangan profesionalisme guru secara berkelanjutan agar meningkatkan kualitas pendidikan guru.

Menurut Zahroh (2015), ada tiga faktor penting yang memengaruhi profesionalisme guru, yaitu guru harus memiliki keahlian khusus, guru harus memiliki kemampuan (keterampilan dan keahlian khusus yang dikuasai) yang dilakukan dengan pelatihan, guru memiliki penghasilan (kompensasi) yang memadai terhadap keahlian khusus yang dimilikinya. Menurut Kopri (2015) motivasi merupakan salah satu factor yang memengaruhi dan menentukan keefektifitasan kerja guru, dengan adanya motivasi yang tinggi profesionalisme guru dapat terlaksana dengan maksimal. Selain itu, menurut (Kristine Lamm \& Elton, 2011; Ulfah, 2014; Soegeng et all., 2014; Cahyani et al., 2017;) menyatakan bahwa motivasi berpengaruh secara positif dan signifikan terhadap profesionalisme guru.

Dalam penelitian (Douglas et al., 2010; Fuad Nazar, et al.,2014; Joni Roza, 2016; Agatha, et al., 2017) menunjukkan pelatihan berpengaruh positif dan signifikan terhadap motivasi kerja karyawan. Menurut (Douglas et al., 2010; Daniatul Firdaus, 2014; Joni Roza, 2016; Agatha, et al., 2017) menjelaskan pelatihan berpengaruh positif dan signifikan terhadap profesionalisme. Berdasarkan hasil penelitian, disimpulkan bahwa kompetensi, pelatihan, dan motivasi, dapat digunakan untuk memprediksi profesionalisme guru. Berdasarkan uraian di atas, peneliti tertarik meneliti untuk mengetahui "Pengaruh Kompetensi dan Pelatihan terhadap Profesionalisme Guru dengan Motivasi sebagai Variabel Intervening di MI, MTs, dan SMK Yayasan Pondok Pesantren Darul Abror Kedungjati". Tujuan dari penelitian ini adalah untuk menganalisis dan mengetahui ada tidaknya pengaruh antara kompensasi, kompetensi dan pelatihan guru terhadap profesionalisme guru dengan motivasi sebagai variabel intervening di MI, MTs, dan SMK Yayasan Pondok Pesantren Darul Abror Kedungjati. Dengan mengetahui besarnya pengaruh tersebut, maka yayasan akan lebih mudah dalam menentukan strategi yang tepat dan sesuai dengan kondisi serta keadaan yang sedang dihadapi unit-unit sekolah di yayasan pondok pesantren darul abror Kedungjati.

\section{TINJAUAN PUSTAKA}

\section{Profesionalisme Guru}

Menurut Surya (2005) Profesionalisme adalah kemampuan, sifat dan sikap mental yang dimiliki seseorang guna mendorong dirinya untuk mewujudkan menjadi guru yang professional. Sedangkan menurut Suyanto dan halimah (2013) Profesionalisme adalah suatu sikap mental yang dimiliki seseorang guna mewujudkan dan meningkatkan kualitas profesionalnya. Menurut Sudarwan Danim dalam Zahroh (2015), menyatakan bahwa profesionalisme adalah suatu usaha untuk mengoptimalkan kemampuan seseorang dalam melaksanakan tuganya menjadi professional dengan lebih meningkatkan kualitas kompetensinya. Menurut Kunandar (2001) Profesionalisme adalah seseorang yang memiliki kemampuan dan wewenang dalam suatu pekerjaan yang dilihat dari situasi, kondisi, sifat dan tujuan seseorang. Sedangkan menurut Kunandar dalam Priansa (2014) Profesionalisme guru adalah seorang guru yang memiliki keterkaitan dengan pekerjaan di bidang pendidikan.

\section{Kompetensi Guru}

Menurut Usman dalam Kunandar (2007) kompetensi adalah suatu hal yang menggambarkan kemampuan dan keahlian seseorang, baik yang secara kualitatif maupun yang kuantitatif. Sementara itu, Piet dan Ida Sahertian dalam Kunandar (2007) kompetensi adalah kemampuan seseorang dalam melaksanakan sesuatu yang diperoleh melalui bidang pendidikan dan pelatihan 
yang bersifat kognitif dan afektif. Sedangkan menurut Barlow (Muhibin Syah, (1995) dalam Daryanto (2013) mengemukakan bahwa kompetensi adalah kemampuan seorang guru dalam melakukan proes pembelajaran dilakukan dengan tanggung jawab yang tinggi sebagai seorang pendidik. Menurut Little (1984) dalam Aminatul Sahroh (2015), Kompetensi adalah dua kekuatan yang sangat berpengaruh, dari kekuatan mental dan fisik yang dimiliki seseorang melalui pelatihan-pelatihan.

\section{Pelatihan Guru}

Pelatihan bagi suatu organisasi merupakan aktivitas yang sangat penting dilakukan, di mana hal tersebut akan memengaruhi tingkat produktivitas kerja dan prestasi kerja bagi tenaga kerja itu sendiri maupun lembaga di mana pekerja tersebut bekerja, sedangkan tenaga kerja yang berada di lingkup sekolah adalah guru. Menurut Bernadian dalam Cardoso (1999), dalam Danang Sunyoto (2015) menjelaskan pelatihan adalah kegiatan untuk meningkatkan prestasi, kemampuan, dan keterampilan seseorang dalam menjalankan tugas kerjanya lebih baik dan optimal, sehingga mendapatkan hasil yang memuaskan. Menurut Benty (2017) pelatihan adalah tindakan yang dilakukan untuk melakukan perbaikan baik dari segi ilmu pengetahuan, maupun tingkat kemampuan seseorang dalam menjalankan pekerjaannya.

\section{Motivasi}

Menurut Susilo (2007) motivasi adalah kegiatan yang bertujuan untuk memengaruhi tindakan seseorang dalam melakukan suatu hal yang sedang kita harapkan. Menurut Kopri (2015), motivasi adalah tindakan untuk mendorong seseorang dalam melakukan suatu perubahan agar bersemangat dalam melakukan suatu pekerjaan sehingga mendapatkan hail yang baik, sesui dengan apa yang dikehendaki. Sedangkan menurut Mc. Donal dalam Sardiman (2005) dalam Kompri (2015) motivasi adalah tujuan seseorang melakukan perubahan baik dari dalam seperti feeling maupun yang dari luar seperti perilaku. Sedangkan menurut Santrok (dalam Mardianto,2012; Kompri,2015), motivasi adalah proses memberikan semangat, arah, dan kegigihan perilaku baik dari dalam maupaun dari luar. Menutur Mitchell (1997) dalam Kompri (2015) Motivasi adalah perubahan yang dilakukan dengan cara memberikan dukungan kepada seseorang untuk mencapai tujuannya.

Adapun model penelitian berdasarkan kajian teori yang telah di uraikan diatas, maka model teoritas yang diajukan adalah sebagai berikut:

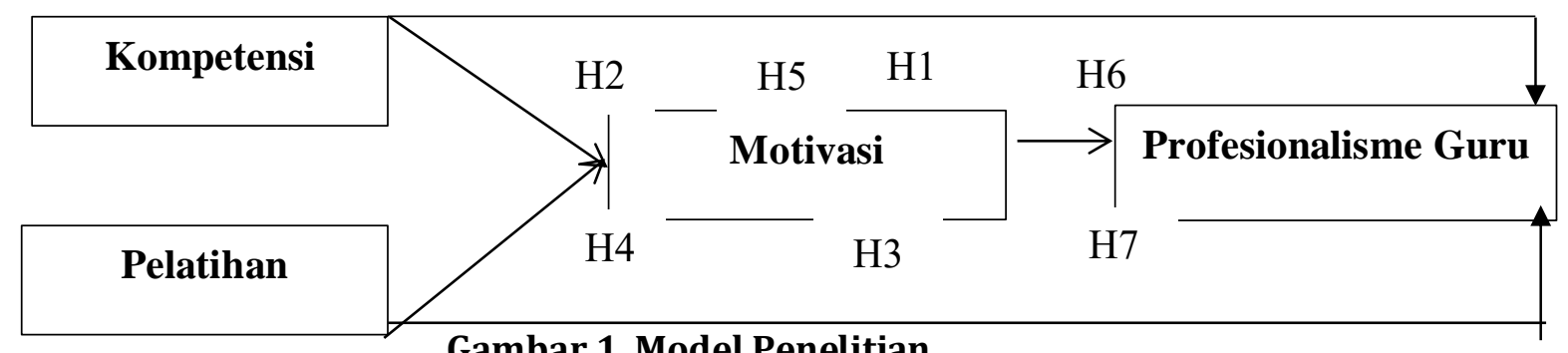

\section{Gambar 1. Model Penelitian}

Hipotesis dalam penelitian ini berdasarkan rumusan masalah, tinjauan pustaka dan penelitian terdahulu adalah :

H1: Kompetensi berpengaruh positif terhadap profesionalisme guru di Yayasan Pondok Pesantren Darul Abror Kedungjati.

H2: Kompetensi berpengaruh positif terhadap motivasi guru di Yayasan Pondok Pesantren Darul Abror Kedungjati.

H3: Pelatihan berpengaruh positif terhadap profesionalisme guru di Yayasan Pondok Pesantren Darul Abror Kedungjati.

H4: Pelatihan berpengaruh positif terhadap motivasi guru di Yayasan Pondok Pesantren Darul Abror Kedungjati. 
H5: Motivasi berpengaruh positif terhadap profesionalisme guru di Yayasan Pondok Pesantren Darul Abror Kedungjati.

H6: Kompetensi berpengaruh positif terhadap profesionalisme guru dengan Motivasi sebagai variabel intervening (mediasi) di Yayasan Pondok Pesantren Darul Abror Kedungjati.

H7: Pelatihan berpengaruh positif terhadap profesionalisme guru dengan Motivasi sebagai variabel intervening (mediasi) di Yayasan Pondok Pesantren Darul Abror Kedungjati.

\section{METODE PENELITIAN}

Metode analisis data yang digunakan dalam penelitian ini adalah metode deskriptif kuantitatif yaitu mencari dan mengumpulkan data yang diperlukan yang bersumber dari sekolah yang akan diteliti. Data yang telah diperoleh diuraikan sehingga memberikan suatu gambaran bagi suatu peneliti. Data yang digunakan sebagai data kuantitatif dalam penelitian ini adalah data nilai PKG dan nilai supervisi guru dari tahun 2017-2018. Metode pengumpulan data yang digunakan dalam penelitian ini dengan menggunakan data primer dan data sekunder. Data primer yang dilakukan dengan mengunakan kuesioner atau angket yang mendukung dan disesuaikan dengan tema penelitian. Sedangkan data sekunder berupa dokumen-dokumen data yang diperoleh untuk melengkapi penelitian. Teknik pengambilan sampel di dalam penelitian ini dengan menggunakan teknik total sampling. Teknik total sampling adalah teknik penentuan sampel semua anggota populasi digunakan sebagai sampel (Arikunto, 2010). Populasi di dalam penelitian ini adalah seluruh guru MI, MTs, dan SMK di Yayasan Pondok Pesantren Darul Abror Kedungjati dengan jumlah 43 guru. Metode analisis data yang digunakan dalam penelitian ini adalah analisis regresi linier berganda dengan menggunakan Software SPSS Versi 16. Analisis regresi berganda merupakan teknik untuk membangun persamaan dan menggunakan persamaan tersebut untuk membuat perkiraan. Hal tersebut menunjukkan bahwa analisis regresi digunakan sebagai analisis prediksi. Karena nilai prediksi tidak selalu tepat dengan nilai rilnya. Semakin kecil tingkat penyimpangan prediksi maka semakin tepat persamaan regresi yang kita bentuk (suliyanto, 2011). Pada Penelitian ini peneliti menggunakan metode pengumpulan data yaitu kuisioner. Metode ini dilakukan dengan cara memberikan kuisioner kepada seluruh guru MI, MTs, dan SMK di Yayasan Pondok Pesantren Darul Abror Kedungjati dimana hasil kuesioner tersebut digunakan peneliti untuk melakukan penelitian.

\section{HASIL DAN PEMBAHASAN}

\section{Gambaran Umum Responden}

Responden penelitian ini seluruh guru MI, MTs, dan SMK di Yayasan Pondok Pesantren Darul Abror Kedungjati, diketahu sebagian besar guru yang menjadi responden perempuan 29 orang (67\%), selebihnya laki-laki 14 orang (33\%). Berdasarkan kelompok usia sebagian besar responden berasal dari kelompok usia kurang dari 30 tahun, sejumlah 21 responden (49\%). Kelompok usia paling sedikit jumlahnya 40-50 tahun 8 responden (18\%). Berdasarkan tingkat pendidikan seluruh guru yang menjadi responden sebagain besar berpendidikan sarjana sebanyak 41 orang (95\%). Responden lainnya lulusan pascasarjana sebanyak 2 orang (5\%). Sedangkan berdasarkan masa kerja diketahui seluruh guru yang menjadi responden sebagian besar mempunyai masa kerja kurang dari 5 tahun 23 orang (53\%). Untuk masa kerja 5 -15 tahun 11 orang (26\%), masa kerja lebih dari 15 tahun 9 orang (21\%).

\section{Uji Validitas dan Reliabilitas Kuesioner}

Uji analisis validitas dan reliabilitas kuesioner penelitian ini meliputi variabel kompetensi (X1), pelatihan (X2), profesionalisme guru (Y), dan motivasi (Z). Dari hasil perhitungan menunjukkan bahwa item pertanyaan dan nilai koefisien reliabitas dari variabel kompetensi (X2), pelatihan (X3), profesionalisme guru (Y), dan motivasi (Z) dalam kuesioner memiliki koefisien korelasi masing-masing lebih besar dari $r_{\text {tabel }}$ 0,3008 artinya semua pertanyaan dalam kuesioner dikatakan valid, sehingga koesioner digunakan sebagai alat ukur penelitian ini. 


\section{Uji Asumsi Klasik}

Berdasarkan perhitungan uji normalitas semua variabel berdistribusi normal yaitu nilai signifikansi dari uji Kolmogrof-Smirnov terhadap nilai standar residual hasil persamaan regresi 0,581 lebih besar dari $\alpha$ sebesar 0,05. Disimpulkan nilai residual terstandarisasi dinyatakan menyebar secara normal atau semua variabel berdistribusi normal. Untuk uji multikolinearitas diketahui bahwa nilai Tolerance (TOL) pada masing-masing variabel kurang dari 1 yaitu, variabel kompetensi (X1) 0,684, variabel pelatihan (X2) 0,789, dan variabel motivasi (Z) 0,523. Sedangkan nilai Variance Inflation Factor (VIF) pada masing-masing variabel bernilai kurang atau lebih kecil dari 10, kompetensi 1,461, pelatihan 1,267 dan motivasi 1,913, dapat disimpulkan bahwa antar variabel bebas tidak mengalami gejala multikolinearitas.

Berdasarkan hasil uji statistik autokorelasi, menunjukkan bahwa nilai Durbin Waston test sebesar 1,904. Angka D-W atau Durbin Waston apabila di antara -2 sampai +2 , itu berarti tidak ada autokorelasi. Berdasarkan hasil uji autokorelasi menunjukkan bahwa model regresi yang digunakan pada penelitian ini tidak terdapat masalah autokorelasi. Untuk uji Heteroskedastisitas, berdasarkan penelitian menunjukkan grafik scatterplot, terlihat titik-titik menyebar secara acak, tidak membentuk sebuah pola tertentu yang jelas, mempunyai pola yang teratur, serta titik-titik tersebar baik di atas maupun di bawah angka 0 pada sumbu Y. Hal tersebut menunjukkan tidak terjadi heteroskedastisitas pada model regresi. Sehingga dapat disimpulkan bahwa tidak ada hubungan antara variabel bebas dengan residual absolutnya dan model regresi layak dipake dan digunakan untuk memprediksi profesionalisme guru.

\section{Pengujian Secara Statistik}

Pengaruh kompetensi dan pelatihan terhadap motivasi

Tabel 4.1 Hasil Uji Analisis Regresi Linier Berganda

\begin{tabular}{|c|c|c|c|c|c|c|}
\hline \multirow{2}{*}{\multicolumn{2}{|c|}{ Model }} & \multicolumn{2}{|c|}{$\begin{array}{c}\text { Unstandardized } \\
\text { Coefficients } \\
\end{array}$} & \multirow{2}{*}{$\begin{array}{c}\begin{array}{c}\text { Standardized } \\
\text { Coefficients }\end{array} \\
\text { Beta }\end{array}$} & \multirow[b]{2}{*}{$\mathrm{T}$} & \multirow[b]{2}{*}{ Sig. } \\
\hline & & B & Std. Error & & & \\
\hline \multirow[t]{3}{*}{1} & (Constant) & 2.056 & 5.237 & & .393 & .697 \\
\hline & Kompetensi & .300 & .104 & .367 & 2.892 & .002 \\
\hline & Pelatihan & .274 & .172 & .201 & 1.590 & .120 \\
\hline
\end{tabular}

a. Dependent Variable: Motivasi

b.

Berdasarkan hasil perhitungan statistik, menunjukkan bahwa persamaan regresi linear

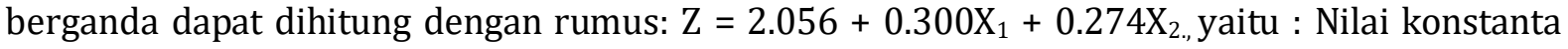
bernilai sebesar 2.056 berarti jika variabel kompensasi, kompetensi, dan pelatihan guru tidak ada perubahan atau konstanta, maka motivasi bernilai 2.056 satuan. Nilai koefisien kompetensi $\left(X_{2}\right)$ 0.300 berarti kompetensi memepunyai hubungan yang positif dengan motivasi, hal ini menunjukkan naiknya kompetensi akan menaikan motivasi. Jika terjadi kenaikan kompetensi sebesar satuan, maka akan menaikan motivasi 0.300 satuan, dengan asumsi bahwa variabel lain tetap pada tingkatan kepercayaan 95 persen. Nilai koefisien pelatihan $\left(X_{3}\right)$ sebesar 0.274 berarti pelatihan mempunyai hubungan yang positif dengan motivasi, hal ini menunjukkan bahwa naiknya pelatihan akan menaikan motivasi. Jika terjadi kenaikan pelatihan sebesar satuan, maka akan menaikan motivasi 0.274 , dengan asumsi bahwa variabel lain tetap pada tingkatan kepercayaan 95 persen.

\section{Analisis Korelasi Antar Ganda}

Berdasarkan perhitungan statistik, menunjukkan bahwa nilai R sebesar 0,691 atau 69,1\%. Hal ini menunjukkan terjadi pengaruh antara kompetensi, dan pelatihan terhadap motivasi guru di MI, MTs, dan SMK Yayasan Pondok Pesantren Darul Abror Kedungjati sebesar 69,1\%, variabel motivasi sebagian dipengaruhi oleh, kompetensi, dan pelatihan, sedangkan sisanya 30,9\% dipengaruhi oleh variabel lain. 


\section{Analisis Determinasi (R1)}

Berdasarkan hasil uji statistik determinasi menunjukkan bahwa nilai $\mathrm{R}^{1}$ menunjukkan angka sebesar 0,477 atau 47,7\%. Hasil ini menunjukkan bahwa ada pengaruh kompetensi, dan pelatihan terhadap motivasi sebesar 47,7\%. Dengan kata lain variabel motivasi sebagian dipengaruhi oleh kompetensi, dan pelatihan, sedangkan sisanya sebesar 52,3\% dipengaruhi oleh variabel lain yang tidak diteliti.

\section{Uji f (secara simultan)}

Berdasarkan hasil pengujian diperoleh nilai $\mathrm{F}_{\text {hitung }}$ sebesar 11,865 dengan nilai Sig sebesar 0,000 lebih kecil dari 0,05. Dengan demikian $\mathrm{H}_{\mathrm{o}}$ ditolak dan $\mathrm{H}_{\mathrm{a}}$ diterima. Artinya kompetensi,dan pelatihan mempunyai pengaruh yang signifikan terhadap motivasi di MI, MTs,dan SMK Yayasan Pondok Pesantren Darul Abror Kedungjati.

\section{Uji t (secara parsial)}

Hasil perhitungan diperoleh nilai signifikansi pada uji t dengan menggunakan tingkat kesalahan $(\alpha)=0,05$ dan degree of freedom, yaitu $\mathrm{n}$ adalah jumlah responden dan $\mathrm{k}$ adalah jumlah variabel penelitian $(n-k=43-4=39)$, diketahui nilai $t_{\text {tabel }}$ sebesar 1,684. Berdasarkan hasil perhitungan nilai $\mathrm{t}_{\text {hitung, }}$ dapat dijelaskan pengaruh masing-masing variabel independent/bebas terhadap variabel dependent/terikat dilihat sebagai berikut: a) Pengaruh kompetensi terhadap motivasi guru MI, MTs, dan SMK di Yayasan Pondok Pesantren Darul Abror Kedungjati. Berdasarkan perhitungan nilai $t_{\text {hitung }}$ kompetensi 2,892 dengan nilai sig 0,002. Dengan menggunakan $\alpha=0,05$ diperoleh nilai $t_{\text {tabel }} 1,684$. Dengan demikian nilai ( $t_{\text {hitung }}>$ nilai $\left.t_{\text {tabel }}\right)$. Hal ini berarti Ho ditolak dan Ha diterima, artinya kompetensi berpengaruh positif signifikan terhadap motivasi guru MI,MTs, dan SMK di Yayasan Pondok Pesantren Darul Abror Kedungjati, hipotesa diterima. b) Pengaruh pelatihan terhadap motivasi guru MI,MTs, dan SMK di Yayasan Pondok Pesantren Darul Abror Kedungjati. Berdasarkan perhitungan nilai $t_{\text {hitung }}$ pelatihan 1,590 nilai sig 0,120. Diperoleh nilai $t$ tabel 1,684. Dengan demikian dari hasil tersebut diketahui bahwa nilai ( $\mathrm{t}_{\text {hitung }}<$ nilai $\left.\mathrm{t}_{\text {tabel }}\right)$. Hal ini berarti Ho diterima dan Ha ditolak, artinya pelatihan tidak mempunyai pengaruh yang signifikan terhadap motivasi guru MI,MTs, dan SMK di Yayasan Pondok Pesantren Darul Abror Kedungjati, hipotesa ditolak.

\section{Pengaruh kompetensi, pelatihan dan motivasi terhadapa profesionalisme guru.}

Perhitungan statistik, hasil regresi linier berganda sebagai berikut:

Tabel 4.19 Hasil Uji Analisis Regresi Linier Berganda

\begin{tabular}{|c|c|c|c|c|c|c|}
\hline \multirow[b]{2}{*}{ Mod } & & \multicolumn{2}{|c|}{$\begin{array}{c}\text { Unstandardized } \\
\text { Coefficients }\end{array}$} & \multirow{2}{*}{$\begin{array}{c}\begin{array}{c}\text { Standardized } \\
\text { Coefficients }\end{array} \\
\text { Beta }\end{array}$} & \multirow[t]{2}{*}{$\mathrm{T}$} & \multirow[t]{2}{*}{ Sig. } \\
\hline & & B & Std. Error & & & \\
\hline \multirow[t]{4}{*}{1} & (Constant) & 11.645 & 8.190 & & 1.422 & .163 \\
\hline & Kompetensi & .702 & .178 & .236 & 2.694 & .003 \\
\hline & Pelatihan & 1.269 & .277 & .594 & 4.574 & .000 \\
\hline & Motivasi & .474 & .250 & .147 & 1.795 & .037 \\
\hline
\end{tabular}

a. Dependent Variable: Profesionalisme_guru

Berdasarkan hasil perhitungan statistik, menunjukkan bahwa persamaan regresi linear berganda dapat dihitung dengan rumus: $\mathrm{Y}=11.645+0.702 \mathrm{X}_{1}+1.269 \mathrm{X}_{2}+0,474 \mathrm{X}_{3}$, Yaitu Nilai konstanta bernilai sebesar 11.645 berarti jika kompetensi, dan pelatihan guru tidak ada perubahan atau konstanta, maka profesionalisme guru bernilai 11.645 satu. Nilai koefisien 
kompetensi (X1) sebesar 0.702 berarti kompetensi memepunyai hubungan yang positif dengan profesionalisme guru, menunjukkan bahwa naiknya kompetensi akan menaikan profesionalisme guru. Jika terjadi kenaikan kompetensi sebesar satu, maka akan menaikan profesionalisme guru sebesar 0.702 satu, dengan asumsi bahwa lain tetap pada tingkatan kepercayaan 95 persen. Nilai koefisien pelatihan (X2) sebesar 1.269 berarti pelatihan memepunyai hubungan yang positif dengan profesionalisme guru, menunjukkan bahwa naiknya pelatihan akan menaikan variabel profesionalisme guru. Jika terjadi kenaikan pelatihan sebesar satu, maka akan menaikan profesionalisme guru sebesar 1.269 satu, dengan asumsi bahwa lain tetap pada tingkatan kepercayaan 95 persen. Nilai koefisien motivasi (X3) sebesar 0.474 berarti motivasi memepunyai hubungan yang positif dengan profesionalisme guru, hal ini menunjukkan bahwa naiknya motivasi akan menaikan profesionalisme guru. Jika terjadi kenaikan pelatihan sebesar satu, maka akan menaikan profesionalisme guru sebesar $0.474 \mathrm{satu}$, dengan asumsi bahwa lain tetap pada tingkatan kepercayaan 95 persen.

Untuk menguji hipotesis, maka perlu adanya ketepatan fungsi regresi sempel dalam melakukan penaksiran nilai aktual agar dapat diukur, hal tersebut dapat dilihat sebagai berikut:

\section{Analisis Korelasi Antar Ganda}

Berdasarkan perhitungan statistik, menunjukkan bahwa nilai R sebesar 0,703 atau 70,3\%. Hal ini menunjukkan terjadi pengaruh antara kompetensi, pelatihan, dan motivasi terhadap profesionalisme guru di MI, MTs, dan SMK Yayasan Pondok Pesantren Darul Abror Kedungjati sebesar 70,3\% variabel profesionalisme guru sebagian dipengaruhi oleh, kompetensi, pelatihan, dan motivasi sedangkan sisanya $29,7 \%$ dipengaruhi oleh variabel lain.

\section{Analisis Determinasi $\left(\mathbf{R}^{2}\right)$}

Berdasarkan hasil uji statistik determinasi menunjukkan bahwa nilai $\mathrm{R}^{2}$ menunjukkan angka sebesar 0,495 atau 49,5\%. Hasil ini menunjukkan bahwa ada pengaruh kompetensi, pelatihan dan motivasi terhadap profesionalisme guru sebesar 49,5\%. Dengan kata lain variabel profesionalisme guru sebagian dipengaruhi oleh kompetensi, pelatihan, dan motivasi sedangkan sisanya sebesar 50,5\% dipengaruhi oleh variabel lain yang tidak diteliti.

\section{Uji f (secara simultan)}

Berdasarkan hasil pengujian diperoleh nilai $\mathrm{F}_{\text {hitung }}$ sebesar 9,302 dengan nilai Sig sebesar 0,000 lebih kecil dari 0,05. Dengan demikian $\mathrm{H}_{\mathrm{o}}$ ditolak dan $\mathrm{H}_{\mathrm{a}}$ diterima. Artinya kompetensi, pelatihan, dan motivasi mempunyai pengaruh yang signifikan terhadap profesionalisme guru di MI, MTs,dan SMK Yayasan Pondok Pesantren Darul Abror Kedungjati.

\section{Uji t (secara parsial)}

Hasil perhitungan diperoleh nilai signifikansi pada uji t dengan menggunakan tingkat kesalahan $(\alpha)=0,05$ dan degree of freedom, yaitu $\mathrm{n}$ adalah jumlah responden dan $\mathrm{k}$ adalah jumlah variabel penelitian, diketahui nilai $t$ tabel sebesar 1,685. Berdasarkan hasil perhitungan nilai $t_{\text {hitung, dapat }}$ dijelaskan pengaruh masing-masing variabel independent/bebas terhadap variabel dependent/terikat dilihat sebagai berikut: a) Pengaruh kompetensi terhadap profesionalisme guru MI, MTs, dan SMK di Yayasan Pondok Pesantren Darul Abror Kedungjati. Berdasarkan

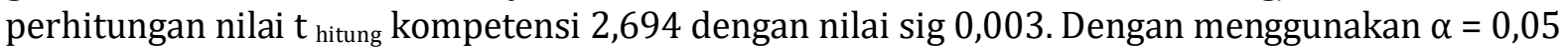
diperoleh nilai $t_{\text {tabel }} 1,685$. Dengan demikian nilai $\left(t_{\text {hitung }}>\right.$ nilai $\left.t_{\text {tabel }}\right)$. Hal ini berarti Ho ditolak dan Ha diterima, artinya kompetensi berpengaruh positif signifikan terhadap profesionalisme guru MI,MTs, dan SMK di Yayasan Pondok Pesantren Darul Abror Kedungjati, hipotesa diterima. b) Pengaruh pelatihan terhadap profesionalisme guru MI,MTs, dan SMK di Yayasan Pondok Pesantren Darul Abror Kedungjati. Berdasarkan perhitungan nilai $t_{\text {hitung }}$ pelatihan 4,574 nilai sig 0,000. Diperoleh nilai $t_{\text {tabel }} 1,685$. Dengan demikian dari hasil tersebut diketahui bahwa nilai $(t$ hitung $>$ nilai $t_{\text {tabel }}$ ). Hal ini berarti Ho ditolak dan Ha diterima, artinya pelatihan mempunyai pengaruh yang signifikan terhadap profesionalisme guru MI,MTs, dan SMK di Yayasan Pondok Pesantren Darul Abror Kedungjati, hipotesa diterima. c) Pengaruh motivasi hadap rofesionalisme 
guru MI,MTs, dan SMK di Yayasan Pondok Pesantren Darul Abror Kedungjati. Berdasarkan perhitungan nilai $t$ hitung motivasi 1,795 nilai sig 0,037 . Diperoleh nilai $t$ tabel 1,685 . Dengan demikian dari hasil tersebut diketahui bahwa nilai $\left(\mathrm{t}_{\text {hitung }}>\right.$ nilai $\left.\mathrm{t}_{\text {tabel }}\right)$. Hal ini berarti Ho ditolak dan Ha diterima, artinya motivasi mempunyai pengaruh yang signifikan terhadap profesionalisme guru MI,MTs, dan SMK di Yayasan Pondok Pesantren Darul Abror Kedungjati, hipotesa diterima.

\section{PEMBAHASAN}

Hipotesis pertama (H1) berbunyi "Kompetensi berpengaruh positif terhadap profesionalisme guru di Yayasan Pondok Pesantren Darul Abror Kedungjati". Berdasarkan hasil penelitian, diperoleh bahwa kompetensi berpengaruh positif dan signifikan terhadap profesionalisme guru MI, MTs, dan SMK di Yayasan Pondok Pesantren Darul Abror Kedungjati. Adapun nilai sig sebesar 0,003 yang berarti memenuhi syarat taraf uji (alfa) $\alpha=0,05$ (5\%) sehingga $\mathrm{H} 1$ diterima, dan dapat dinyatakan bahwa kompetensi berpengaruh positif dan signifikan terhadap profesionalisme guru. Hasil hipotesis ketiga ini mendukung penelitian terdahulu yang dilakukan oleh Sudja et al (2013); Noor et al (2015) menjelaskan bahwa hasil penelitian kompetensi guru memiliki pengaruh yang signifikan terhadap profesionalisme guru. Menurut Yin Cheong Cheng (2010) menunjukan bahwa kompetensi berpengaruh positif dan signifikan terhadap profesionalisme guru. Dengan demikian disimpulkan bahwa guru yang memiliki kompetensi tinggi, maka guru tersebut akan memiliki profesionalisme yang tinggi, begitu pula sebaliknya apabila guru memiliki kompetensi yang rendah, maka guru tersebut mempunyai profesionalisme yang rendah pula. Kompetensi guru MI, MTs, dan SMK di Yayasan Pondok Pesantren Darul Abror Kedungjati, berdasarkan hasil penelitian dalam kategori baik. Guru yang memiliki kompetensi dan profesional yang baik seharusnya guru dapat melaksananakan tugas pokoknnya dengan baik sesuai dengan fungsinya, guru dapat melaksananakan dengan baik proses belajar mengajar di dalam kelas.

Hipotesis kedua (H2) berbunyi "Kompetensi berpengaruh positif terhadap motivasi guru di Yayasan Pondok Pesantren Darul Abror Kedungjati". Berdasarkan hasil penelitian, diperoleh bahwa kompetensi berpengaruh positif dan signifikan terhadap motivasi guru MI, MTs, dan SMK di Yayasan Pondok Pesantren Darul Abror Kedungjati. Adapun nilai sig sebesar 0,002 yang berarti memenuhi syarat taraf uji (alfa) $\alpha=0,05$ (5\%) sehingga H2 diterima, dan dapat dinyatakan bahwa kompetensi berpengaruh positif dan signifikan terhadap motivasi guru. Artinya dengan adanya kompetensi yang tinggi akan meningkatkan motivai guru, sehingga dengan adanya dorongan intrinsik (dorongan dari dalam) dan ekstrinsik (dorongan dari luar) yang dimiliki semakin menumbuhkan motivasi guru. Hasil hipotesis keempat ini mendukung penelitian terdahuluoleh Arumwanti et al (2012) bahwa kompetensi bernilai positif, hal ini menunjukkan bahwa pengaruh kompetensi searah dengan motivasi kerja. Artinya bila kompetensi karyawan suatu perusahaan baik akan berdampak positif terhadap motivasi kerja. Dengan demikian dapat disimpulkan bahwa guru yang memiliki kompetensi tinggi, maka guru tersebut akan memiliki motivasi yang tinggi, begitu pula sebaliknya apabila guru memiliki kompetensi yang rendah, maka guru tersebut mempunyai motivasi yang rendah.

Hipotesis ketiga (H3) berbunyi "Pelatihan berpengaruh positif terhadap profesionalisme guru di Yayasan Pondok Pesantren Darul Abror Kedungjati". Berdasarkan hasil penelitian, diperoleh bahwa pelatihan berpengaruh positif dan signifikan terhadap profesionalisme guru MI, MTs, dan SMK di Yayasan Pondok Pesantren Darul Abror Kedungjati. Adapun nilai sig sebesar 0,000 yang berarti memenuhi syarat taraf uji (alfa) $\alpha=0,05$ (5\%) sehingga H3 diterima, dan dinyatakan bahwa pelatihan berpengaruh positif dan signifikan terhadap profesionalisme guru. Berdasarkan hasil penelitian ini pelatihan dapat digunakan untuk memprediksi profesionalisme guru di MI, MTs, dan SMK Darul Abror Kedungjati. Hasil hipotesis kelima ini mendukung penelitian terdahulu yang dilakukan oleh menurut Agatha,et al (2017) hasil penelitian tentang pengaruh pelatihan berpengaruh positif dan signifikansi terhadap profesionalisme guru. Berdasarkan analisis pelatihan mempunyai kontribusi signifikan terhadap peofesionalisme guru, artinya profesionalsime guru SD di kabupaten Tulungagung akan tinggi apabila mendapatkan 
pelatihan. Dengan demikian dapat disimpulkan guru yang sering melakukan pelatihan maka guru tersebut akan memiliki profesionalisme yang baik, begitu pula sebaliknya apabila guru jarang atau tidak sering dalam melakukan pelatihan, maka guru tersebut mempunyai profesionalisme yang rendah. Pelatihan guru MI, MTs, dan SMK di Yayasan Pondok Pesantren Darul Abror Kedungjati, berdasarkan hasil penelitian dalam kategori baik.

Hipotesis keempat (H4) berbunyi "Pelatihan berpengaruh positif terhadap motivasi guru di Yayasan Pondok Pesantren Darul Abror Kedungjati”. Berdasarkan hasil penelitian, diperoleh bahwa pelatihan tidak berpengaruh positif dan signifikan terhadap motivasi guru MI, MTs, dan SMK di Yayasan Pondok Pesantren Darul Abror Kedungjati. Adapun nilai sig 0,120 berarti memenuhi syarat taraf uji (alfa) $\alpha=0,05$ (5\%) sehingga $\mathrm{H} 4$ ditolak, dan dapat dinyatakan bahwa pelatihan tidak berpengaruh signifikan terhadap motivasi guru. Berdasarkan hasil penelitian menunjukkan bahwa pelatihan sudah cukup baik namun belum bisa menjamin dalam memperbaiki motivasi guru di MI, MTs, dan SMK Darul Abror Kedungjati. Hasil hipotesis keenam tidak mendukung penelitian terdahulu yang dilakukan oleh Fuad Nazar, et al (2014); Darmawan, et al (2017) menyatakan bahwa ada pengaruh positif dan signifikan antara variabel pelatihan terhadap motivasi kerja. Selain itu ada penelitian terdahulu yang mendukung yaitu Idah Ayu, et al (2014) dalam penelitiannya menunjukkan bahwa pelatihan tidak berpengaruh signifikan terhadap motivasi guru. Hal ini menunjukkan bahwa pelatihan yang dilakukan di MI, MTs, dan SMK Darul Abror Kedungjati tergolong cukup baik namun belum menjadi jaminan dalam memperbaiki motivai guru. Hal ini terbukti dengan semakin baiknnya pelatihan yang diberikan maka semakin baik dan meningkat pula motivasinya.

Hipotesis kelma (H5) berbunyi "Motivasi berpengaruh positif terhadap profesionalisme guru di Yayasan Pondok Pesantren Darul Abror Kedungjati. Berdasarkan hasil penelitian, motivasi berpengaruh positif dan signifikan terhadap profesionalisme guru MI, MTs, dan SMK di Yayasan Pondok Pesantren Darul Abror Kedungjati. Adapun nilai sig sebesar 0,037 berarti memenuhi syarat taraf uji (alfa) $\alpha=0,05$ (5\%) sehingga H7 diterima, dinyatakan bahwa motivasi berpengaruh positif dan signifikan terhadap profesionalisme guru. Hal ini menunjukkan motivasi dapat meningkatkan kualitas guru dan memberi dampak positif terhadap profesionalisme guru di MI, MTs, dan SMK di Yayasan Pondok Pesantren Darul Abror Kedungjati. Hasil hipotesis kelima mendukung penelitian terdahulu menurut Menurut Hildebrandt, et al (2011); Soegeng, et al (2014) ; Ahmad Tanzeh, et al (2015) menyatakan bahwa pengaruh motivasi kerja terhadap profesionalisme guru menunjukkan hasil yang positif dan signifikan, jika motivasi kerja meningkat maka profesionalisme guru juga akan meningkat. Berdasarkan hasil pengujian penelitian tersebut dapat diambil kesimpulan bahwa seorang guru yang memiliki motivasi yang tinggi akan meningkatkan kemampuan, pengetahuan, dan kualitas kerjanya, sehingga profesionalisme guru dapat meningkat di MI, MTs, dan SMK di Yayasan Pondok Pesantren Darul Abror Kedungjati.

Hipotesis keenam (H6) berbunyi" Kompetensi berpengaruh positif terhadap profesionalisme guru dengan Motivasi sebagai variabel intervening (mediasi) di Yayasan Pondok Pesantren Darul Abror Kedungjati". Berdasarkan hasil penelitian, kompetensi berpengaruh positif dan signifikan terhadap profesionalisme guru melalui motivasi sebagai variabel mediasi/intervening di MI, MTs, dan SMK di Yayasan Pondok Pesantren Darul Abror Kedungjati. Adapun besar sumbangan efektif dari kompetensi terhadap profesionalisme guru secara langsung $(\mathrm{a})=2,602$ atau 26,02 persen lebih kecil dari nilai pengaruh tidak langsung dari kompetensi terhadap hasil profesionalisme melalui motivasi (bxc) $=81,13$ atau 81,13 persen. Hal tersebut menunjukkan hubungan langsung lebih kecil dari koefisien hubungan tidak langsung, maka dikatan hubungan yang sebenarnya adalah hubungan tidak langsung dengan menggunakan variabel mediasi. Hal ini berarti hipotesis keenam menyatakan kompetensi berpengaruh positif dan signifikan terhadap profesionalisme guru dengan motivasi sebagai variabel intervening. Menurut Sudja (2013) kompetensi berpengaruh signifikan dan positif terhadap profesionalisme guru. Berdasarkan penelitian terdapat pengaruh yang positif dan signifikan secara bersama-sama antara kompeteni dan motivasi terhadap profesionalisme guru di MI, MTs, dan SMK di Yayasan Pondok Pesantren Darul Abror Kedungjati. 
Hipotesis ketujuh (H7) berbunyi "Pelatihan berpengaruh positif terhadap profesionalisme guru dengan Motivasi sebagai variabel intervening (mediasi) di Yayasan Pondok Pesantren Darul Abror Kedungjati". Berdasarkan hasil penelitian, variabel pelatihan berpengaruh positif dan signifikan terhadap profesionalisme guru melalui motivasi sebagai variabel mediasi/intervening di MI, MTs, dan SMK di Yayasan Pondok Pesantren Darul Abror Kedungjati. Adapun besar sumbangan efektif dari variabel kompetensi terhadap profesionalisme guru secara langsung (a) = 2,395 atau 23,95 persen lebih kecil dari nilai pengaruh tidak langsung dari pelatihan terhadap hasil profesionalisme melalui motivasi (bxc) $=11,2007$ atau 11,20 persen. Hal tersebut menunjukkan hubungan tidak langsung lebih kecil dari koefisien hubungan langsung, maka dapat dikatan bahwa hubungan yang sebenarnya adalah hubungan langsung dengan menggunakan variabel mediasi. Hal ini berarti hipotesis ketujuh pelatihan berpengaruh positif dan signifikan terhadap profesionalisme guru dengan motivasi sebagai variabel mediasi/intervening. Menurut Budi Mulyawan (2012) hasil penelitian menjelaskan pengalaman pelatihan menjadi faktor paling besar memengaruhi profesionalisme guru. Berdasarkan hasil penelitian diambil kesimpulan bahwa terdapat pengaruh yang positif dan signifikan secara bersama-sama antara pelatihan dan motivasi sebagai variabel mediasi atau intervening terhadap profesionalisme guru di MI, MTs, dan SMK di Yayasan Pondok Pesantren Darul Abror Kedungjati

\section{KESIMPULAN DAN SARAN}

\section{Kesimpulan}

Berdasarkan pembahasan hasil penelitian yang telah dikemukakan di atas maka dapat diambil kesimpulan bahwa terdapat hubungan yang positif dan signifiksn secara sendiri-sendiri maupun secara bersama-sama antara kompetensi, pelatihan guru, motivasi, dan profesionalisme guru. Selain itu, penelitian ini juga membuktikan bahwa kompetensi, dan pelatihan merupakan faktor yang memengaruhi profesionalisme secara langsung maupun tidak langsung dengan motivasi sebagai variabel mediasi/variabel intervening. Hal ini menjelaskan bahwa semakin tinggi kompetensi dan pelatihan maka guru akan semakin termotivasi dalam melakukan kegiatan pembelajaran sehingga profesionalisme guru semakin meningkat.

\section{IMPLIKASI}

Berdasarkan pembahasan, hasil penelitian dan kesimpulan yang telah dilakukan, maka terdapat saran yang dapat diberikan sebagai berikut:

Untuk sekolah, diharapkan dapat digunakan sebagai bahan reverensi, bahan informasi perkembangan ilmu pengetahuan, dan bahan evaluasi mengenai pentingnya profesionalisme guru untuk meningkatkan kualitas kompetensi guru sebagai pendidik. Untuk kepala Madrasah, diharapkan penelitian ini sebagai bahan pertimbangan, pengambilan kebijakan dan keputusan untuk meningkatkan kompensasi, kompetensi, pelatihan, dan motivasi terhadap profesionalisme guru, sehingga dapat meningkat. Untuk guru, diharapkan dapat memberikan informasi, sumbangan pemikiran dan acuan bagi guru guna meningkatkan profesionalismenya sebagai pendidik dalam pelaksanaan pembelajaran di sekolah.

Untuk Penelitian Selanjutnya, Bagi peneliti selanjutnya yang ingin melakukan penelitian atau melanjutkan penelitian, disarankan untuk meneruskan atau melakukan pengembangan penelitian ini dengan mencari faktor-faktor lain yang memengaruhi profesionalisme guru tidak yang tidak diungkap dalam penelitian ini. Sehingga diharapkan untuk penelitian selanjutnya dapat mengungkap profesionalisme guru berdasarkan faktor-faktor lain.

\section{DAFTAR PUSTAKA}

Ali. 2012. Pengaruh Motivasi Kerja, Komunikasi dan Komitmen terhadap Profesionalisme Guru IPA SMP Di Rayon Sabatu Kaupaten Paregi Moutung. Jurnal Mitra Sains 5 (4) : 1-11

Agatha Maria, Muhammad Anasrulloh, dan Nailariza Umami .2017. Kontribusi Pelatihan Terhadap Profesionalsime guru sekolah dasar di kabupaten Tulungagung. Journal Prosiding 2 (4) : 1-11 
Pengaruh Kompetensi dan Pelatihan Guru Terhadap Profesionalisme Guru dengan Motivasi Sebagai Variabel Intervening di MI, MTs, dan SMK Yayasan Pondok Pesantren Darul Abror Kedungjati.

Alkmal, Zaldi, A.Rahman Lubis,Mukhlis Yunus. 2012. Pengaruh Kompensasi Terhadap Motivasi dan Disiplin Serta Dampaknya Pada Kinerja Pegawai Sekertariat Daerah Aceh Unsyiah. Fakultas Ekonomi Universitas Syiah Kuala Banda Aceh, Aceh, Indonesia.

Arikunto, Suharsimi. 2010. Prosedur Penelitian Suatu Pendekatan Praktik (edisi keenam). Jakarta: Rineke Cipta.

Budiman,Jumardi. 2016. Pengaruh Kompensasi Terhadap Motivasi Kerja Guru Tidak Tetap (GTT) Di Kecamatan Meliau Kabupaten Sanggau. Fakultas Ekonomi Universitas Skolah Tinggi Ilmu Ekonomi Indonesia Pontianak, Pontianak, Indonesia.

Cahyani,I. Eko, Sunandar, dan Yovitha Yilejantiningsih.2017. Pengaruh Kepemimpinan Kepala Sekolah, Kompensasi, dan Ikim Kerja Terhadap Profesionalsime Guru Di SD Negeri Se-Kecamatan Slawi Kabupaten Tegal. Fakultas Ekonomi Universitas PGRI Semarang, Semarang, Indonesia.

Cheng, Yin Cheong. 2010. Relation Between Teachers' Professionalism and Job Attitudes, Educational Outcomes, and Organizational Factors. Chinese : the chinese university of hong kong. Journal of Educational Research,Vol. 89, No. 3, pp. 163-17

Darmawan,Yuyun Yuniar, Wayan Gede Supartha, Agoes Ganesha Rahyuda. 2017. Pengaruh Pelatihan Terhadap Motivasi dan Kinerja di Prama Santur Beach-Bali. Bali.Tesis Fakultas Ekonomi Universitas Udayana.

Daryanto. 2013. Standar Kometensi dan Penelitian Kinerja Guru Profesional. Yogyakarta: Gava Media.

Douglas N.Harris Tim R.Sass. 2011. Teacher training, teacher quality and student achievement. Journal of Public Economics Vol. 95, Issues 7-8, pp798-812

Erpidawati dan Rantih Fadhlya Adri. 2017. Pengaruh Motivasi Kerja dan Insentif terhadap Kinerja Profesionalsime guru SD Muhammdaiyah Kota Padang. Padang: Universitas Muhammadiyah Sumatra Barat. Journal penelitian dan kajian ilmiah menara ilmu Vol. 11, No. 77

Firdaus, Daniatul. 2014. Pengaruh Tingkat Pendidikan Pelatihan, dan Pengalaman Mengajar Terhadap Profesionalisme Guru Di Madrasah Tsanawiyah Negeri Kediri 2. Kediri: STAIN Kediri. Journal of Islamic Education Vol 2, No 2

Gunawan, Imam, dan Djum Djum Noor Benty. 2017. Manajemen Pendidikan Suatu Pengaruh Praktik. Bandung : Alfabet Bandung.

Hasibuan, Malayu. 2017. Manajemen Sumberdaya Manusia. Jakarta: PT Bumi Aksara.

Hildebrand Susan A and MinheeEom. (2010). Teacher professionalization: Motivational factors and the influence of age. Journal Teaching and Teacher Education.Vol.27, issue 2, pp 416-423

Kopri. 2015. Motivasi Pembelajaran. Bandung: PT Remaja Rosdakarya.

Kristine LammWest and EltonMykerezi. 2011. Teachers' unions and compensation: The impact of collective bargaining on salary schedules and performance pay schemes. Journal Economics of Education Review.Vol. 30, Issue 1, pp 99-108

Kunandar. 2001. Guru Profesional Implementasi Kurikulum Tingkat Satuan Pendidikan (KTSP) dan Sukses dalam Sertifikasi Guru. Jakarta : PT Rajagrafindo Persada.

Martoyo,Susilo. 2007. Manajemen Sumberdaya Manusia. Yogyakarta: BPFE-Yogyakarta.

Miyono, Noor dan Nur Makhsun. 2015. Kompetensi dan Budaya Kerja Guru Dalam Membentuk Profesionalisme Guru Madrasah Ibtidaiyah di Kabupaten Temanggung. Temanggung: Universitas PGRI Semarang. Journal Manajemen Pendidikan JMP Vol. 6, No. 3

Mulyasa. 2013. Standar Kompetensi dan Sertifikasi Guru. Bandung : PT Remaja Posdakarya.

Mulyawan, Budi. 2012. Pengaruh Pengalaman dalam Pelatihan terhadap Peningkatan Kompetensi Profesional Guru. Singaraja : Undiksha Singaraja.

Nazar, Fuad Endang, Siti Astuti Muhammad, dan Faisal Riza.2014. Pengaruh Pendidikan dan Pelatihan Terhadap Motivasi dan Kinerja Karyawan. Journal Administrasi Bisnis. Vol. 13, No. 1 
Ngatemin, dan Wanti Arumwanti. 2012. Pengaruh Kompetensi dan Kompensasi terhadap Motivasi Kerja Karyawan Hotel di Kaupaten Karo Provinsi Sumatra Utara. Journal Riset Akuntasi dan Bisnis Vol. 13, No. 1

Priansa, D. Juni. 2014. Kinerja dan Profesionalisme guru. Bandung: Alfabeta.

Rahmawati, Sri, Syahir Natsir dan Mauled Moelyono. 2015. Pengaruh Pelatihan, Pengalaman Mengajar dan Kompensasi Terhadap Profesionalisme Guru di SMK Negeri 3 Palu. Journal Katalogis Universitas Tadulako, Vol. 3, No. 12

Roza, Joni. 2016. Pengaruh Pelatihan dan Pengalaman Mengajar Terhadap Profesionalsime Guru Madrasah Aliyah Negeri (MAN) Di Kabupaten Tanah Datar.Journal Manajemen Pendidikan Vol. 4, No. 2

Rusman. 2017. Belajar dan Pembelajaran Berorientasi Standar Proses Pendidikan. Jakarta: PT Karisma Putra Utama.

Singarimbun, Masri dan Sofian Effendi. 2006. Metode Penelitian Suvai. LP

Sugiyono. 2015. Metode Penelitian Pendidikan Pendekatan Kuantitatif, Kualitatif, R dan D. Bandung: Afabeta.

Sugiyono. 2015. Statistik Non Parametris untuk Peneitian. Bandung: Afabeta.

Suliyanto. 2011. Ekonomietrika Terapan : Teori dan Aplikasi Degan SPSS. Yogyakarta; Penerbit ANDI.

Sudana, I. Wayan. 2015. Pengaruh Kompensasi Terhadap Motivasi dan Kepuasan Kerja Karyawan di Grand Puncak Sari Restauran Kintamani.Tesis Fakultas Ekonomi Universitas Udayana Bali.

Sudjana, I. Nengah, Amiartuti Kusmaningtyas. 2013. Pengaruh Kompetensi, Kepemimpinan Diri, Sistem Penghargaan, Lingkungan Kerja Terhadap Komitmen Pada Profesi dan Profesionalsime Guru SMA Negeri di Bali. Journal DIE Vol. 9, No. 2

Sunardi. 2011. Pengaruh Pendidikan dan Pelatihan, Supervisi Akademik dan Kegiatan Pengembangan Profesi Terhadap Profesionalisme Guru di SMP Negeri 1 Sigaluh. Purwokerto, Tesis Fakultas Ekonomi Universitas Jenderal Soedirman Purwokerto.

Sunyoto, Danang. 2015. Manajemen dan Pengembangan Sumberdaya Manusia. Yogyakarta: CARS

Supriyanto, Arie dan Tawil. 2014. Pengaruh Insentif, Pelatihan, Komunikasi dan Kepemimpinan Terhadap Motivasi Kerja Guru SD Mutual Kota Magelang. Magelang; FKIP UM Magelang. Journal Bina Matria Vol. 3, No. 2

Surya, Moh. 2005. Percikan Perjuangan Guru. Semarang: CV. Aneka Ilmu Anggota IKAPI.

Suyanto dan Asep Djihad. 2013. Bagaimana Menjadi Calon Guru dan Guru Profesional. Yogyakarta : Multi Pressindo.

Tanzah, Ahmad dan Achmad Patoni. 2015. Pengaruh Motivasi Kerja, Komunikasi dan Komitmen Terhadap Profesionalisme Guru di MTs Negeri Se-Kabupaten Trenggalek. Journal Administrasi Pendidikan, Vol. 2, No.2

Ulfah, Choinyah, Yovitha Yuliejantiningsih, dan AY Soegeng. 2014. Pengaruh Tingkat Pendidikan, Pelatihan, dan Pengalaman Mengajar Terhadap Profesionalsitas Guru di Madrasah Tsanwiyah Negeri Kediri 2. Kediri: STAIN Kediri. Journal Of Islamic EducationVol.2, No.2

W, Veronika Ellyana Dian, Mintasih Indriayu, dan Sudarno. 2016. Pengaruh Kompensasi Guru Terhadap Motivasi Belajar Siswa Pada Mata Pelajaran Kewirausahaan di SMK Kristen 1 Surakarta. Surakarta: Tesis Fakultas Ekonomi Universitas Sebelas Maret.

Wajihidin, Mohamad, M. Fathorrazi, Diana Sulianti K Tobing . 2010. Pengaruh Kompensasi dan Budaya Organisasi Terhadap Profesionalisme Guru Dengan Kepuasan Kerja dan Komitmen Organisasi Sebagai Variabel Intervening (Studi Kasus di MTs Miftahul Ulum Banyu Putih Kidul Jatiroto Lumajang). Lumajang: Universitas Jember. Jurnal Relasi,Vol 10, No 2

Waryanto. 2010. Pengaruh Kompetensi Pedagogik Guru Pendidikan dan Komitmen Organisasi Terhadap Profesionalisme Guru SMP Negeri di Kecamatan Kampung Laut Kabupaten Cilacap. Tesis Fakultas Ekonomi dan Bisnis Universitas Jenderal Soedirman Purwokerto.

Widya, Maria Agasha. 2013. Kontribusi Pelatihan Terhadap Profesionalisme Guru Sekolah Dasar di Kabupaten Tulungagung. Journal Prosiding vol.2 No.4 
Pengaruh Kompetensi dan Pelatihan Guru Terhadap Profesionalisme Guru dengan Motivasi Sebagai Variabel Intervening di MI, MTs, dan SMK Yayasan Pondok Pesantren Darul Abror Kedungjati.

Wulansari, Puspita. 2014. Pengaruh Kompensasi Terhadap Motivasi Karyawan Di Departemen Sumberdaya Manusia PLN Kantor Distribusi Jawa Barat dan Banten. Banten: Universitas Telkom. Journal Manajemen Indonesia, Vol. 14. No. 2

Zahroh, Aminatul. 2015. Membangun Kualitas. Pembelajaran Melalui Dimensi Profesionalisme Guru. Bandung: Yrama Widya. 